\title{
Using Story to Understand Teacher Knowledge
}

\author{
Stefinee Pinnegar, Eliza Pinnegar, and Celina Dulude Lay
}

\begin{abstract}
The knowledge preservice teachers bring is experiential, grounded in stories they've lived and told. Because of the way story captures experience, it's valuable in the learning-to-teach process. In this commentary, we return to narrative research we completed to consider the stories preservice teachers tell in learning to teach. We explore what we know about teaching from stories we've told and consider how story positions teacher educators. These explorations provide narrative insights that guide us in developing stronger teachers. These stories allow us to build on teacher knowledge as well as disrupt preconceptions and beliefs within their teacher education.
\end{abstract}

\section{Background}

Clandinin (2010) argues that the basis in preparing teachers should be teacher knowledge which emerges from the experiences of those learning to teach. In contrast, most teacher education programs are guided by knowledge of teaching which begins with categorization and fragmentation of theory, conceptions of best practices, and so forth. When teacher knowledge guides us, we attend to preservice teachers' experience and personal practical knowledge which form their basis in learning to teach. As Bullough (1989) argued, who teachers become as teachers emerges from who they are as humans.

The knowledge preservice or even inservice teachers bring to the learning-to-teach process is experiential-grounded in the stories they have lived and told. Thus, in teacher education, attending to experience as represented in story could lead to the development of more innovative, grounded, and continually evolving teachers. Because of the way story captures experience, we see it as valuable for the learning to teach process. As Polkinghorne (1988) argues, story has the capacity to bring together multiple plots, distort yet represent elements of time, and capture without totalizing characters like students, principals, parents, and other teachers. This makes narrative a stronger vehicle for representing knowing and meaning in human interaction and praxis. Because of these characteristics, story both builds on and disrupts teacher knowledge.

As we consider Polkinghorne's argument, we are struck with the way in which narrative is seen as story and story is seen as narrative and yet their value in studying teaching and learning to teach is obscured when they are treated as synonymous. Clandinin and Connelly (2000) argue moving to narrative we live, tell, retell, and relive story. Narrative begins in experience. From experience, we shape and form stories. We decide what is the beginning, middle, and end; how details are orchestrated, which characters populate the story, and how the plotline is arranged. The story we tell becomes one possible account of the experience. Retelling stories opens space for considering and reconsidering, viewing elements from 
different angles and imagining them differently. Reliving stories involves the ways in which retelling shifts our knowing of experience, ourselves, and the meanings we hold of things like teaching and learning.

By differentiating conceptions of story and narrative, we are positioned to explore how we have used story in learning to teach. In some cases, we use story (simple, authentic accounts of experiences). In other cases, we use narrative because we have engaged in that process of living, telling, retelling, and reliving.

In this commentary, we return to narrative research that we completed (Lay, 1998; Murphy, Pinnegar, \& Pinnegar, 2011; Pinnegar, 1996). We consider the stories preservice teachers tell in learning to teach and explore what we know about teaching from stories we have told and the narrative understandings that emerged as we examined these stories. Finally, we consider how attention to story positions us as teacher educators through stories we tell about teaching teachers and their development and how these explorations provide narrative insights that can guide us in developing stronger teachers.

\section{Stories Preservice Teachers Tell About Teaching}

When using story in educating preservice teachers, their stories can provide two sources for support and disruption in the education of teachers. The first is the experience they have had, as learners or as teachers in different roles and settings, and the ways it forms their personal practical knowledge for teaching. In Murphy et al. (2011), we see how early life experiences and earlier teaching experience inform and shape learning to teach. Sometimes these stories serve as moral and ethical filters. When the stories are told and retold, they thrust teacher candidates into new relationships with teacher education.

Through her experiences as a teacher assistant, Eliza shows how she negotiated tensions between a difficult child, Jeff, and the Head Teacher of the class, Karen. As tensions grew between Jeff and Karen, Eliza realized the need to stay in relation with both. A token reward system had been put into place as a way to reward children who displayed good behavior, while it was also used as punishment for negative behavior. Eliza's teacher knowledge, as well as her knowledge of teaching, made her uncomfortable with this practice, but she realized that she alone could not change the policy in favor for one that seemed more ethical to Eliza. Later, in a teacher preparation course, Eliza had difficulty with the professor in her English as a Second Language class. Eliza worried that her negative feelings toward the professor, and the stories that the teacher represented, would affect who she would be as a teacher. Eliza realized the impact that her teacher preparation could have on her future teaching. As Eliza would continue to have the professor for other courses, she worried that her relationship with the professor would change how Eliza taught those subjects as well. Eliza realized that she had to forgive her professor at the beginning of the new semester if she was going to be able to develop into the kind of teacher she wanted to be. Eliza shows that teacher education is not just about the learning of subject matter and procedures for an effective classroom, but to learn the intangible qualities of being a teacher and working in education. They also show how experiences, and the stories that are told of those experiences, can disrupt the simplified image of teacher as someone who simply loves children and teaches at the front of a classroom. 
In Lay (1998), we see how studying stories of teachers can provide insight into their growth and development. Lay and her colleagues, who were all student teachers, met together during their student teaching experience and told stories from it. Initially, they could not form coherent stories. Their ability to tell comprehensible stories improved, indicating growth and insight into these teachers' individual experiences. Teachers and university supervisors knowing of the student teaching experience would be both supported and reformed since the individual stories provided needed insight into how preservice teachers experience student teaching. In her analysis of these stories, Lay was able to construct a metanarrative of the plotline of successful accomplishment of teacher preparation. According to Lay, the stories uncovered a pattern contained in the label "student teaching." Preservice teachers began as students and their stories reflected that they positioned themselves as students in relationship to and in interpretation of their supervisors' advice. They then needed to move from student to student teacher and in this move they began to see their interaction with students and their interactions with supervisors differently. Finally, by the end of student teaching, successful preservice teachers storied themselves as teachers. One of the participants moved from student to student teacher to teacher, but in her last stories moved back to the student position and never took up teaching. As we look at Lay's analysis, we see that preservice teachers begin in their stories focusing on themselves and their personal reactions, but then their focus moved to students and learning.

Preservice teachers bring experiences and stories to their learning to teach experience. As Hammersley's work (2006) indicates, the interpretations of their experiences and the goals they have underlie their orientation to learning from their teacher education curriculum. Preservice teachers have a vision of who they want to be as a teacher and what they need to learn to do that both disrupt and shape their learning. Analysis of preservice teachers' stories can disrupt and enrich our understanding of how preservice teachers experience learning to teach, their development, and points of intervention or support. Preservice teachers' stories are useful whether they are clichéd or unique-what they reveal can support teacher educators in creating stronger teachers. Using story allows us as teacher educators to disrupt, support, and gain insight into their learning to teach.

\section{What We Know About Teaching From the Stories Inservice Teachers Tell}

From stories Stefinee (Pinnegar, 1996) told as a teacher educator returning to teaching, she discovered the way in which living, telling, retelling, and reliving experience (moving experience to story to narrative) was a pathway that teachers used to learn from their teaching. Stefinee told of not being sure how to tell an experience, forming it into a story, retelling the story by altering its dimensions, and then articulating the ways in which she could live differently in her teaching as a result. Stefinee discussed this as problem representation. Meaning the original formulation of the experience into the story constituted a way to represent experience. Taking alternative perspectives and retelling the story opened spaces for learning. Finally, in the text Stefinee expressed commitments she made to act differently and to think differently about her teaching.

Telling a story of her anticipation that something was going down in the classroom, but she couldn't tell what or how she knew that, uncovered an understanding that she knew things in her body about what 
was happening in the classroom. Moving story to narrative allowed Stefinee to recognize how stories from teachers uncover their personal practical knowledge and allow it to grow and change-how telling stories of teaching opens space for teacher learning and development. In examining her experiences with the teacher that she worked with, she realized she and the teacher experienced the classroom and teaching differently, and the stories each told of a shared experience clearly revealed those differences.

\section{The Stories Teacher Educators Tell to Teachers}

Teacher educators tell stories of their experiences in classrooms. Stefinee (Pinnegar, 1996) explored how she told stories in her adolescent development class to guide and support student learning. She held particular purposes for storytelling in her course. She wanted students to gain experience in analyzing adolescent experience, determine implications, and plan responses. This enabled her students to think and act in these ways when they taught adolescents. Moving stories to narrative, she covered additional purposes_-stories create community, develop space where students could safely share (written or spoken) stories that made them vulnerable, and the need to present content. Stefinee constantly faced a conundrum between her ethical responsibility for stories to carry course content and provide space for students to link experience to theory and research. Her past experience of storytelling as conversation interfered with the strategic way she used story in teaching teachers. Like explaining jokes, overexplaining a story can kill its value to the learner. Further, her understanding that in authentic settings the story is told and interpretation left open, conflicted with my purpose to engage students in explaining the connections between experience and course content. Because of her conflicting purposes (creating trust and space, storytelling responses by students, and narrative structure), she found herself monitoring the tension between the teachability and tellability of stories. As the course developed, students shared experiences that linked stories read or told to experiences of their own and connected it to content, either telling a story that disagreed or was in concert with the content. Stefinee uncovered a pattern of storytelling where she left empty nodes in her discourse and wait time to draw students into sharing relevant stories and working as a class to link stories and content.

\section{Conclusion and Discussion}

In The Call of Stories, Robert Coles (1989) provides compelling evidence that the literary stories and poems his students read influenced their moral decisions in their professional as well as their personal lives. The characters and events of the stories became a vital part of the cadre of memories and experiences about which his students puzzled and from which they reasoned in examining their own experience and making choices for their lives.

It is through the stories that preservice and inservice teachers hold of teaching and learning to teach, that they are able to attend to their experiences in ways that aid their development and allow them to evolve in their teaching. As teacher educators, using story, and helping those we work with inquire into those stories and move them to narratives, these stories allow teacher educators to build on teacher knowledge as well as disrupt preconceptions and beliefs within their teacher education. 


\section{References}

Bullough, R.V. Jr. (1989). First year teacher: A case study. New York, NY: Teachers' College Press.

Clandinin, J. (2010). Learning to teach: A question of knowledge, Education in Canada, 40, 27-30.

Clandinin, D.J., \& Connelly, F.M. (2000). Narrative inquiry: Experience and story in qualitative research. San Francisco, CA: Jossey-Bass.

Coles, R. (1989). The call of stories: Teaching and the moral imagination. Boston, MA: Houghton-Mifflin.

Hammersley, K. (2006). Seeing through teachers' eyes: Professional ideals and classroom practices. New York, NY: Teachers College Press.

Lay, C.D. (1998). Beliefs in conflict: Narratives of student teaching. Honors Thesis. Brigham Young University.

Murphy, M. S., Pinnegar, E., \& Pinnegar, S. (2011). Exploring ethical tensions on the path to becoming a teacher. Teacher Education Quarterly, 38(4), 97-113.

Pinnegar, S. (1996). Sharing stories: A teacher educator accounting for narrative in her teaching. Action in Teacher Education, 18(3), 13-22.

Polkinghorne, D. E. (1988). Narrative knowing and the human sciences. Albany, NY: State University of New York Press. 


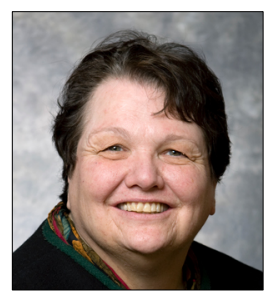

Stefinee Pinnegar is a graduate of the University of Arizona and an Associate Professor of Teacher Education at Brigham Young University. Her research interests focus on teacher thinking, teacher development, and self-study. In examining the development of teacher thinking, she has particular interest in the development of practical memory for teaching. In terms of self-study, she is interested in the methodology of self-study and the improvement of her practice as a teacher educator. In terms of professional development, she has studied how attending to the research-based characteristics of teacher learning leads to teacher change.

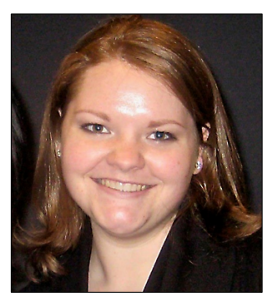

Eliza Pinnegar began her work in education in day- and after-school care. She has a degree in Elementary Education and has taught first grade, and is a graduate of the University of Alberta with a Masters and PhD. Her master's thesis was a narrative inquiry with D. Jean Clandinin focused on teachers who graduated in teaching but didn't teach. Her doctoral research explored the experiences of children in afterschool/daycare classrooms. She has published in Teaching Education, Mentoring and Tutoring and Teacher Education Quarterly. She is an active participant in Narrative Research, ISATT, and S-STEP research methodology communities.

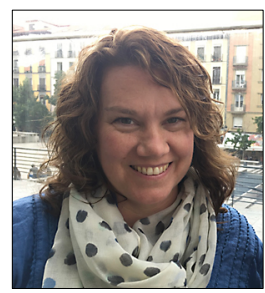

Celina Dulude Lay has a Master's degree of Education with an emphasis in literacy from the University of Utah. She is an adjunct instructor and doctorate student at Brigham Young University in Provo, Utah. From the time she was an undergraduate, she has been involved in teacher education research and interested in the preparation and development of educators. Her first research experience was a narrative self-study, exploring the experiences of student teachers of English moving into their roles as teachers. Currently, she is involved in a self-study project of the teacher identity of teachers who prepared, taught, and left teaching. 